\title{
Bioavailability, ecotoxicity, and geological characteristics of trace lead in sediments from two sites on Negro River, Uruguay, South America
}

\author{
Diana M. Míguez · Raquel Huertas • María V. Carrara · Agustín Carnikián · \\ María E. Bouvier • María J. Martínez · Karen Keel · Carolina Pioda • \\ Elena Darré $\cdot$ Ramiro Pérez $\cdot$ Santiago Viera $\cdot$ Enrique Massa
}

Received: 30 March 2010/Accepted: 11 April 2011/Published online: 4 October 2011

(C) Springer Science+Business Media B.V. 2011

\begin{abstract}
Bioassays of two sites along the Rio Negro in Uruguay indicate ecotoxicity, which could be attributable to trace concentrations of lead in river sediments. Monthly samples at two sites at Baygorria and Bonete locations were analyzed for both particle size and lead. Lead was determined by atomic spectrometry in river water and sediment and particle size by sieving and sedimentation. Data showed that Baygorria's sediments have greater percentage of clay than Bonete's (20.4 and $5.8 \%$, respectively). Lead was measurable in Baygorria's sediments, meanwhile in Bonete's, it was always below the detection limit. In water samples, lead was below detection limit at both sites. Bioassays using sublethal growth and survival test with Hyalella curvispina amphipod, screening with bioluminescent bacteria Photobacterium leiognathi, and acute toxicity bioassay
\end{abstract}

D. M. Míguez $(\bowtie) \cdot$ M. V. Carrara · A. Carnikián ·

M. E. Bouvier · M. J. Martínez - K. Keel

Water and Chemicals Department, Technological

Laboratory of Uruguay (LATU), Avda. Italia 6201,

PO Box: 11500, Montevideo, Uruguay

e-mail: dmiguez@latu.org.uy

R. Huertas · C. Pioda · E. Darré · R. Pérez · S. Viera

Food and Environmental Atomic Spectrometry

Department, Technological Laboratory of Uruguay

(LATU), Avda. Italia 6201, PO Box: 11500,

Montevideo, Uruguay

E. Massa

National Geological Survey (DINAMIGE), Hervidero

2861, PO Box: 11800, Montevideo, Uruguay with Pimephales promelas fish indicated toxicity at Baygorria, with much less effect at Bonete. Even though no lethal effects could be demonstrated, higher sublethal toxicity was found in samples from Baygorria site, showing a possible concentration of the contaminant in the clay fraction.

Keywords Bioavailability $\cdot$ Bioassays $\cdot$ Lead · Permian

\section{Introduction}

Lead is a toxic heavy metal that can be deposited in bed sediments, usually associated with particulate matter composed of iron and manganese oxides. Thus, sediments become a route of exposure to lead for aquatic organisms. Benthic organisms ingest water and sediment and come in contact with particulate, dissolved and sediment-bound lead. Lead associated with sediment fractions that exhibit cation-exchange capacity or are easily reduced is generally more bioavailable than that associated with other fractions. Furthermore, changes in ambient environmental conditions can increase the bioavailability of lead associated with inorganic solid phases and organic matter (CCME 1999). Lead is a non-essential element, toxic to biota at elevated concentrations. In nature, lead occurs in its monovalent $\left(\mathrm{Pb}^{1+}\right)$, divalent $\left(\mathrm{Pb}^{2+}\right)$, and tetravalent $\left(\mathrm{Pb}^{4+}\right)$ states, with divalent $\mathrm{Pb}$ being the most common. Lead can also form organometallic 
compounds, such as tetraethyl lead, which was the largest single source of lead emissions to the atmosphere in Uruguay prior to January 2004, when it was used as antiknock additive in gasoline. Lead has been shown to be carcinogenic in the gastrointestinal tract, respiratory system, and kidneys of human and animal receptors (Merian 1991).

Lead-bearing bottom sediments found in the northwestern area of the Negro River, Uruguay, are mainly derived from Gondwanan fine-grained sediments'. Suspended clay particles from these units, together with humates from decay of vegetation, are responsible for the characteristic water color (Bossi and Navarro 1988). The clay fraction is a laminated structure of phyllosilicate with $\mathrm{SiO}_{4}$ and alumina groups. The minerals are montmorillonite and illite of 2:1 structure, alternated with aluminum gibbsite. The source sediments were deposited under oxidative conditions during the Carboniferous period, beginning with extended till deposits, associated with varvic lutite, sand, and sea level deposits, indicative of circumpolar conditions. Sediments with a carbonous fraction rich in fossil vegetation and bituminous lutite deposited during the Permian period. Over this, there are deposits mainly constituted of clay, with levels of bituminous lutites (Bossi op. cit.).

Benthic invertebrates are in close contact with the sediment, as they live on its surface, buried in it or ingesting particles. For this reason, they become suitable organisms to determine the effects of sediment contaminants on the aquatic biota, through toxicity tests (Reynoldson and Day 1993). Amphipods, such as Hyalella azteca, are one of the international reference species used to assess sediment toxicity. However, in order to study the sensitivity of an ecologically relevant species representative of the area under study, the amphipod Hyalella curvispina (Crustácea: Peracárida: Amphipoda) of the genus Hyalella (Smith, 1874), exclusively South American, was chosen to evaluate the toxicity. H. curvispina has been used previously in laboratory studies to assess the sludge toxicity by $\mathrm{Di}$ Marzio et al. (1999), as well as in in situ studies with confined organisms within limnocages set on the stream bottom sediment (Graça et al. 2002; Jergentz et al. 2004), showing its sensitivity to toxicants. This genus is composed of several species that inhabit diverse freshwater hábitats, lenthic or lothic, associated to aquatic vegetation, and in some cases, to groundwater environment. In one unique case, they are associated to woods
(Grosso and Peralta 1999). H. curvispina is a very abundant amphipod in water courses in Argentina, Uruguay, and Brazil (González 2003; Jergentz et al. 2004; Graça et al. 2002). Organisms of this species can be found living on hard substrates, aquatic vegetation and algae, and stream benthos (Poi de Neff and Carignan 1997; Casset et al. 2001; Poretti et al. 2003). Their role is important in the trophic web of the freshwater ecosystems, favoring the cycling of organic matter due to their habit of grazing on ephyphites and phytobenthos, the sediment and detritus ingestion, and being eaten for other invertebrates and fish (Giorgi and Tiraboschi 1999; Casset et al. 2001).

Bioluminescent bacteria has been used as a screening method for on-site detection of a wide range of organic and inorganic toxicants, such as heavy metals, pesticides, herbicides, chlorinated hydrocarbons, polychlorinated biphenyls, benzene, toluene, and other toxicants (Ulitzur et al. 2002). Various environmental chemicals, such as parabens, have been tested using Toxscreen 3 to assess toxicity within batteries of bioassays, including this screening test (Bazin et al. 2010). These bacteria are facultative anaerobes, so they can perform both fermentative and respiratory metabolic functions. However, the microbe demonstrates less luminescence when exposed to oxygen and/or low salt concentrations. (Balows 2005). This method uses a strain of Photobacterium leiognathi and two assay buffers: one for detecting heavy metals (Pro-Metal buffer) and the other for organic pollutants (Pro-Organic buffer), which are designed to discriminate between the presence of organic and metal toxicants at less than milligram per liter concentrations (US EPA, Environmental Technology Verification Report 2006). Under the test conditions, luminous bacteria emit luminescence that can be calibrated with standards. Toxicants, such as the ones listed before, exert a dramatic and measurable effect on a bacterial luminescence system. By comparing the luminescence level obtained in a suspected toxic sample with that obtained in a clean water control sample after a short period of incubation, very low concentrations of a broad range of toxicants can be detected.

\section{Aim \\ The aim of the research was to determine whether lead could be linked to the toxic effects evidenced through}


bioassays on sediment and water samples on two sites of Negro River and to assess whether its bioavailability could be correlated to the grain-size characteristics and/or to the clay fraction of the sediment due to the geological formation.

\section{Materials and methods}

\section{Experimental design}

In general, sediment toxicity is assumed to primarily be a problem for benthic (sediment-dwelling) organisms through ingestion of re-suspended sediments and also of dissolved metals released from sediment particles. Therefore, it is advisable to measure ecotoxicity using both benthic and water column-dwelling species (Ranville et al. 2007). Thus, in order to evaluate lead bioavailability to aquatic organisms, the concentration of the metal was both measured in the water column and in the whole sediment, and a suite of bioassays and screens was applied to assess toxic effects. Particle size was analyzed to evaluate the sediment composition and how this factor was affecting the uptake and toxicity of the metal. The importance of the particle size determination was due to potential correlations with contaminant levels, and finer grain sediments frequently relate to higher contaminant concentrations. Particle size of sediments was determined by sieving and sedimentation. In this research, we used the amphipod Hyalella curvispina in whole sediment. The reference fish Pimephales promelas was used to evaluate the water column toxicity, as it is an internationally recognized method. A screening method using luminescent bacteria Photobacterium leiognathi (Toxscreen 3) was also applied to explore the organism responses at several trophic levels and to be able to estimate whether the contamination could be due to organic or to metallic agents.

\section{Sampling}

From August 2008 to June 2009, monthly samples of sediment and water of the Negro River were taken at Rincon del Bonete $\left(32^{\circ} 51^{\prime} 09^{\prime \prime} \mathrm{S}, 56^{\circ} 26^{\prime} 34.2^{\prime \prime} \mathrm{W}\right)$ and Baygorria $\left(32^{\circ} 51^{\prime} 09.8^{\prime \prime} \mathrm{S}, 56^{\circ} 47^{\prime} 17.4^{\prime \prime} \mathrm{W}\right)$, Uruguay. Sediment samples were obtained using an Ekman grab at one margin of the river, and water samples were taken from the surface into 10-1 polypropylene plastic containers. In sediment, particle size, lead, and the acute bioassay using Hyalella curvispina were performed. The screening method using the bacteria Photobacterium leiognathi was applied to an 1:4 elutriate to assess metal and organic toxicity. The Pimephales promelas ecotoxicity bioassay was used to assess lead toxicity in the water column.

\section{Particle size analysis}

Prior to analysis, approximately $100 \mathrm{~g}$ of sediment was passed through a $2-\mathrm{mm}$ sieve, to separate the gravel from the grains less than $2-\mathrm{mm}$ in diameter. Afterward, approximately $20 \mathrm{~g}$ of sediment sample was treated with hydrogen peroxide to oxidize the organic matter. The excess hydrogen peroxide was destroyed by boiling. The residue was then dried overnight in the oven at $105 \pm 5^{\circ} \mathrm{C}$ and weighted. The percent sand was isolated by wet sieving through a no 325 ASTM sieve to a measuring cylinder of 1 liter. The silts and clays were determined using "The Pipette Method" based on Stoke's law. The sand percentage was dry sieved through a set of sieves (ASTM mesh numbers: 20, 40, 60, and 170), then it was characterized according to the USDA System (FAO 1984). Particle sizes were reported as percentages of the total sample weight (FAO 1984).

Lead analysis

Lead in sediment was determined by atomic spectrometry according to ASTM 3976-02/EPA 3051A/ ISO11885 (2007) modified. Also, lead was determined in river water by atomic spectrometry according to ISO15586 (2003). Prior to analysis, approximately $100 \mathrm{~g}$ of sediments was passed through a $2-\mathrm{mm}$ plastic sieve, dried in an oven at less than $60^{\circ} \mathrm{C}$, and then grounded in an ceramic mortar following ASTM D3976-92 (2005).

Microwave oven digestion: following the USEPA method 3051A, sediments samples were digested $(1.0 \mathrm{~g})$ in Tetrafluormethaxil (TFM) Teflon ${ }^{\mathrm{TM}}$ vessels with $10 \mathrm{ml} \mathrm{HNO}_{3} 65 \%$ using microwave heating (Milestone MLS 1200 MEGA). After cooling down, $20 \mathrm{ml}$ of water was added, and the solution obtained homogenized. A Perkin-Elmer ${ }^{\circledR}$ Model A Analyst 200 atomic absorption spectrometer equipped with a HGA-900 graphite furnace with deuterium background correction was used for water analysis 
according to ISO $15586: 03$, and a Perkin-Elmer ${ }^{\circledR}$ Model OPTIMA 2100 DV optical emission spectrometer was used for sediments analysis using ISO 11885:07 (5) adapted. A $1000 \mathrm{ug} \mathrm{ml}^{-1}$ lead standard solution (Merck ${ }^{\mathrm{TM}} \mathrm{KGaA}$ Germany) certified by the manufacturer to $\pm 2 \mathrm{mg} \mathrm{l}^{-1}$ and traceable to NIST (National Institute of Standards and Technology, Gaithersburg, MD, USA) was used to prepare standard solutions with ultrapure water (water with a specific resistivity of $18 \mathrm{M} \Omega \mathrm{cm}$ obtained by filtering distilled water through a Milli-Q Plus purifier system (Millipore Corp, Bedford, MA, USA)). Direct calibration against standard solutions was carried out for water analysis and by the standard addition method for sediments. The limits of detection (LOD) and quantification (LOQ) obtained in this study were as follows: in the water testing, LOD $0.002 \mu \mathrm{g} \mathrm{ml}^{-1}$ and LOQ $0.010 \mu \mathrm{g} \mathrm{ml}^{-1}$, while for sediment testing, LOD: $2.0 \mathrm{mg} \mathrm{kg}^{-1}$ and LOQ: $5.0 \mathrm{mg} \mathrm{kg}^{-1}$.

\section{Ecotoxicity tests}

Acute toxicity tests in the water column were carried out with the fry stages of the fish Pimephales promelas. The starter culture was kindly provided by U.S. EPA, EERD. The culture conditions in our laboratory were as follows: $16: 8$ photoperiod, medium hardness water, and Artemia sp. and Tetramin ${ }^{\circledR}$ scales were used for feeding. Two male fish and four female were maintained in breeding tanks with PVC halfpipes used as spawning substrate. The method was developed exposing 10 larvae in $200 \mathrm{ml}$ of sample volume in polypropylene beakers for $96 \mathrm{~h}$ according to USEPA 821-R-02-012 (2002). Lethality was checked using the Probit method (Finney 1978).

For the whole-sediment toxicity test, the growth and survival method with the amphipod Hyallela curvispina was based on USEPA 600/R-99/064 Test Method 100.1, 2000, modified. The starter culture organisms for $H$. curvispina were collected in a relatively pristine pond after acclimation in the laboratory inside aquaria, and medium hardness water was used to replace the original water. The culture conditions in our laboratory were as follows: temperature at $23 \pm 2^{\circ} \mathrm{C}, 16: 8$ photoperiod, ambient light at 400-800 lux, and medium hardness water. A culture of the microalgae Selenastrum capricornutum
Printz (= Pseudokirchneriella subcapitata (Korshikov) Hindak, ISO/TC N 182, 1999) (cited by Pavlic et al. 2005) was added along with a suspension of yeast plus organic lettuce leaves for feeding. Thirty juveniles (organisms with 7-14 of life) were used to determine the initial mean weight by drying in the oven overnight at $60 \pm 5^{\circ} \mathrm{C}$ and weighting to $0.01 \mathrm{mg}$. A control and a blank were also carried out. The exposition was static, with continuous aeration, and growth and lethality were assessed after the 10 days exposure period. Ten organisms of between 7 and 14 years old were exposed to the sediments, in $400 \mathrm{ml}$ polypropylene vessels. The volume of sediment added to the vessel was $100 \mathrm{ml}$, and the volume of culture water was $175 \mathrm{ml}$. The end points analyzed were survival and growth (as dry weight). The data obtained were statistically evaluated applying a $t$ test for comparing the mean survivals of the samples against the control, and an ANOVA test for comparing the final weights.

Screening method with the bacteria Photobacterium leiognathi (ToxScreen3, Checklight ${ }^{\circledR}$ )

The luminescent marine bacterium $P$. leiognathi was employed according to the instructions in protocol found at Checklight ${ }^{\circledR}$ PCB-TOX (ToxScreen3) User Guide and applied to the sediment elutriate (1:4). The ToxScreen 3 test was done using the elutriate working at room temperature and measuring the light intensity with a portable luminometer. The elutriate preparation was done using all stainless steel equipment composed of an axial mechanic mixer and a beaker, proceeding according to US EPA standard elutriate preparation. The mixture was stirred for $30 \mathrm{~min}$ and after that at $10 \mathrm{~min}$ intervals, stirred manually to ensure complete mixing. After the 30-min mixing period, mixture was allowed to settle for $1 \mathrm{~h}$, and supernatant siphoned off without disturbing the settled material (USEPA-USACOE 1998).

\section{Results}

Table 1 Lead concentration in sediments at Baygorria and Bonete from August 2008 until June 2009. 
Table 1 Lead concentration in sediment $\left(\mathrm{mg} \mathrm{kg}^{-1}\right)$ (as $\left.\mathrm{Pb}\right)$

\begin{tabular}{lll}
\hline Sampling date & Baygorria & Bonete \\
\hline $12 / 08 / 2008$ & $<10$ & $<10$ \\
$01 / 10 / 2008$ & $<5$ & $<1.5$ \\
$14 / 10 / 2008$ & $<1.5$ & $<1.5$ \\
$16 / 12 / 2008$ & 12 & $<3.7$ \\
$14 / 01 / 2009$ & 9.6 & $<3.0$ \\
$27 / 01 / 2009$ & 6.9 & $<3.0$ \\
$10 / 02 / 2009$ & 8.3 & $<5.0$ \\
$10 / 03 / 2009$ & 7.6 & $<5.0$ \\
$17 / 03 / 2009$ & 7.8 & $<5.0$ \\
$14 / 04 / 2009$ & 8 & $<5.0$ \\
$12 / 05 / 2009$ & 8.6 & $<2.0$ \\
$09 / 06 / 2009$ & 7.2 & $<4.0$ \\
\hline
\end{tabular}

Table 2 Whole-sediment toxicity testing with Hyalella curvispina and water column bioassays and screen

\begin{tabular}{|c|c|c|c|c|}
\hline & Elutriat & & Sediment & Water \\
\hline & $\begin{array}{l}\text { P. leiog } \\
\text { leiogna }\end{array}$ & $\begin{array}{l}\text { athi } \\
\text { ii }\end{array}$ & $\begin{array}{l}\text { H. } \\
\text { curvispina }\end{array}$ & P. promelas \\
\hline & IC50 $(n$ & $=1)$ & Mean & LC50 \\
\hline & Metals & Organics & & \\
\hline $\begin{array}{l}\text { Baygorria } \\
(\%)\end{array}$ & 1.8 & 2.3 & 94 & $>100$ \\
\hline $\begin{array}{c}\text { Bonete } \\
(\%)\end{array}$ & 6.3 & 69.3 & 83 & $>100$ \\
\hline
\end{tabular}

Ecotoxicity tests

Table 2 below shows the acute toxicity fish test results, the bacterial screen performed with sediment elutriate (1:4), and the amphipod whole-sediment test.
In average, the composition of sediment in the two river location varies greatly, showing higher percentage of clay for Baygorria site compared to Bonete, as can be seen on the Fig. 2.

Figure 2 Average yearly sediment composition for Baygorria and Bonete.

\section{Discussion}

As noted in Fig. 1, the particle size distributions at the sites under study are completely different. This could be explained by a geographical difference, Baygorria site is before a dam and Bonete is after a dam. Thus, there is a more stagnant flow at the first one, which leads to a higher settling rate and accumulation of finer particles. Data on Fig. 2 illustrate that Baygorria's sediments in average have greater percentage of clay than Bonete's (20.4 and 5.8\%, respectively). Table 1 shows that lead determination was quantifiable in Baygorria's sediments, meanwhile lead concentrations in Bonete's sediments were always below the quantification limit. Lead concentrations of water samples were also always below the quantification limit $\left(0.01 \mathrm{mg} \mathrm{l}^{-1}\right)$, which is lower than the national regulation limit $\left(0.03 \mathrm{mg} \mathrm{l}^{-1}\right.$, as $\mathrm{Pb}$ ) for stream water (Decreto 253/79 1979).

Preliminary results of Hyalella curvispina growth and survival test in the sediment samples suggest a possible relationship that needs to be confirmed between lead concentration, clay percentage, and mean body weight obtained after the exposure of juvenile specimens to the sediments from Baygorria site. Although lead concentrations found in sediments from Baygorria are below the TEL ( $34 \mathrm{mg} \mathrm{kg}^{-1}$, as $\mathrm{Pb}$ ) determined for the reference amphipod Hyalella
Fig. 1 Grain-size distribution for Baygorria's and Bonete's sediments according to USDA system
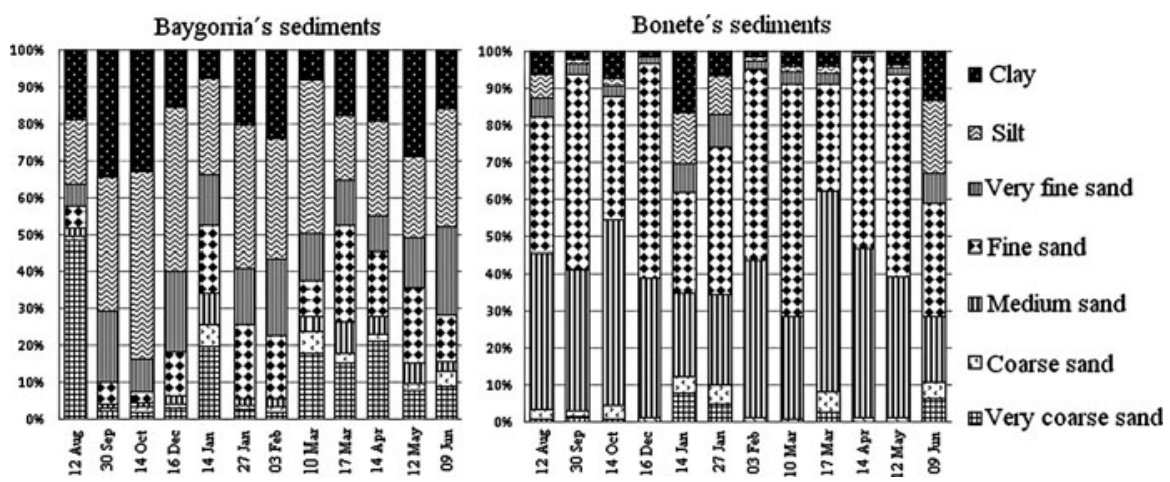
Fig. 2 Yearly average composition, according to USDA classification

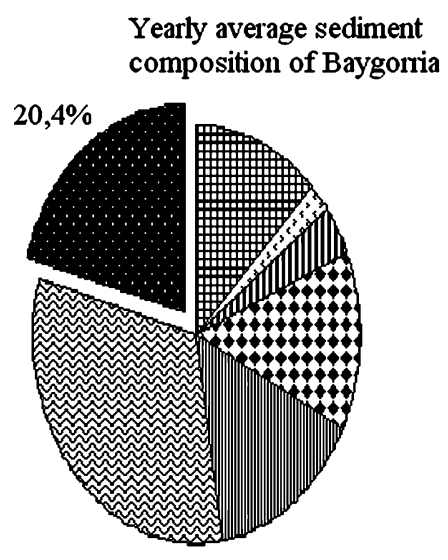

Yearly average sediment

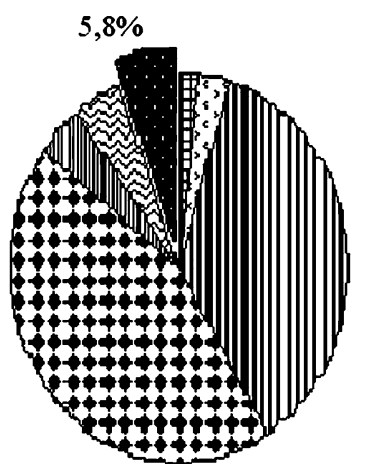

Yearly average sediment composition of Bonete

alay

Silt

mVery fine sand

$\mathbf{\nabla}$ Fine sand

In Medium sand

๑Coarse sand

田Very coarse sand azteca (Bonnet 2000) and below the Canadian sediment quality guidelines for the protection of aquatic life, the analytical results suggest that the growth of the native amphipod Hyalella curvispina could be affected at this site.

It has been hypothesized by some authors that particle size would affect both organism exposure to and toxicity of lead-contaminated sediments, and indirectly, when dissolved metal exposure is dominant due to the metal partitioning between dissolved and sorbed phases (Ranville et al. 2007). Our findings also preliminarily suggest that this hypothesis could be supported in the case under study.

\section{Conclusions}

These sub-lethal effects, which appear to be related to the sediments particle size, can have an important effect on aquatic ecosystems, as sustained by Ranville et al. (2007). In our research, these preliminary results suggest that higher toxicity was found in Baygorria when compared to Bonete's sediment samples, based on the sub-lethal toxicity and screen results. It could be postulated that the bioavailability of lead to organisms that interact with the sediment increases with higher clay fractions. However, an influence of other contaminants, for example, organics, cannot be discarded due to the results obtained by the screening test with Photobacterium leiognathi. However, no toxicity was observed in the water column, which correlates with the very low concentrations of toxicants detected in this matrix. These findings should be confirmed by further research, including sampling at other sites and applying bioassays for longer periods.

Acknowledgments The poster version of this study was presented in 2009 at the third Hemispheric Conference on Medical Geology, of the International Medical Geology Association, Montevideo, Uruguay. The experimental work of this research was performed at the Technological Laboratory of Uruguay (LATU). Thanks to the sampling team, Water and Chemical Department and Environmental Department, LATU, for performing the sediment sampling. We thank Judith Loureiro for her comments on factors affecting sediment composition and contamination.

\section{References}

ASTM D3976-92. (2005). Standard Practice for Preparation of Sediment Samples for Chemical Analysis.

Balows, A., et al. (2005). The Prokaryotes (2nd ed.,Vol. 2). In: Brenner, D. J., et al. (eds.), Bergey's manual of systematic bacteriology, New York.

Bazin, I., Gadal, A., Touraud, E., \& Roig, B. (2010) Hydroxy benzoate preservatives (Parabens) in the environment: Data for environmental toxicity assessment. In D. Fatta-Kassinos, et al. (eds.), Xenobiotics in the urban water cycle, mass flows, environmental process, mitigation and treatment strategies, environmental pollution, Vol. 16, Chap. 14, doi: 10.1007/978-90-481-3509-7_14.

Bonnet, C. (2000). Développement de bioessais sur sédiments et applications à l'étude, en laboratoire, de la toxicité de sédiments dulçaquicoles contaminés. Metz: Thèse Université de Metz.

Bossi, J., Navarro, R. (1988). Geología del Uruguay, Tomos I y II. Edición Depto. de Publicaciones de la Universidad de la República.

Canadian Council of Ministers of the Environment (CCME). (1999). Canadian sediment quality guidelines for the protection of aquatic life: Lead.

Casset, M. A., Momo, F. R., \& Giorgi, A. (2001). Dinámica poblacional de dos especies de anfípodos y su relación con 
la vegetación acuática en un microambiente de la cuenca del río Luján (Argentina). Ecología Austral, 11, 79-85.

Decreto 253/79 (Con las modificaciones de los Decretos 232/88, 698/89 y 195/91 incluidas). (1979). http://www.dinama. gub.uy/profesionales/downloads/dec_253_79.pdf.

Di Marzio, W. D., Sáenz, M. E., Alberdi, J. L., \& Tortorelli, M. C. (1999). Assessment of the toxicity of stabilized sludges using Hyalella curvispina (Amphipod) bioassays. Bulletin of Environmental Contamination and Toxicology, 63, 654-659.

FAO, Distribución de tamaño de partícula (Análisis Mecánico). (1984). Métodos físicos y químicos de análisis de suelos y aguas. Boletín de la FAO 10 (pp. 36-46). Roma, Italia.

Environmental Technology Verification Report (2006). Checklight ltd., Toxscreen-II test kit, US Environmental Protection Agency. http://epa.gov/etv/pubs/600etv06054.pdf.

Giorgi, A., \& Tiraboschi, B. (1999). Evaluación experimental del efecto de dos grupos de macroinvertebrados (anfípodos y gasterópodos) sobre algas epífitas. Ecología Austral, 9, 35-44.

González, E. (2003). The freshwater amphipods Hyalella Smith, 1874 in Chile (Crustacea:Amphipoda). Revista Chilena de Historia Natural, 76, 623-637.

Graça, M., Rodrígues-Capítulo, A., Ocón, C., \& Gómez, N. (2002). In situ tests for water quality assessment: A case study in Pampean rivers. Water Research, 36, 4033-4040.

Grosso, L., \& Peralta, M. (1999). Anfípodos de agua dulce sudamericanos Revisión del género Hyalella Smith. I. Acta Zoológica Lilloana, 45, 79-98.

ISO11885:07. (2007). Water Quality: Determination of selected elements by inductively coupled plasma optical emission spectrometry (ICP-OES).

ISO15586:03. (2003). Water Quality: Determination of trace elements using atomic absorption spectrometry with graphite furnace.

Jergentz, S., Pessacq, P., Mugni, H., Bonetto, C., \& Schulz, R. (2004). Linking in situ bioassays and population dynamics of macroinvertebrates to assess agricultural contamination in streams of the Argentine pampa. Ecotoxicology and Environmental Safety, 59, 133-141.
Merian, E. (1991). Metals and their compounds in the environment, occurrence, analysis and biological relevance. VCH Verlagsgesellschaft $\mathrm{mbH}$, Weinheim. New York: VCH Publishers Inc.

Pavlic, Z., Vidakovic-Cifrek, Z., \& Puntaric, D. (2005). Toxicity of surfactants to green microalgae Pseudokirchneriella subcapitata and Scenedesmus subspicatus and to marine diatoms Phaeodactylum tricornutum and Skeletonema costatum. Chemosphere, 61, 1061-1068.

Poi de Neff, A., \& Carignan, R. (1997). Macroinvertebrates on Eichhornia crassipes roots in two lakes of the Paraná river floodplain. Hydrobiología, 345, 185-196.

Poretti, T. I., Casset, M. A., \& Momo, F. (2003). Composición y dinámica poblacional de Hyalella curvispina en el arroyo Las Flores (Cuenca del río Luján). Biología Acuática, 20.

Ranville, J., Clements, W., Macalady, D., Ross, P., \& Lasat, M. (2007). Final Report: The particle size distribution of toxicity in metal-contaminated sediments, Research Project Search, National Center for Environmental Research, US Environmental Protection Agency. http://cfpub.epa, gov/ncer_abstracts/index.cfm/fuseaction/display.abstract Detail/abstract/360/report/F.

Reynoldson, T. B., \& Day, K. E. (1993). Freshwater sediments. In P. Calow (Ed.), Handbook of ecotoxicology, Vol. 1 (1st ed., pp. 83-100). Oxford: Blackwell.

Ulitzur, S., Lahav, T., \& Ulitzur, N. (2002). A novel and sensitive test for rapid determination of water toxicity. Environmental Toxicology, 17(3), 291-296.

US Environmental Protection Agency. (2002). Methods for measuring the acute toxicity of effluents and receiving waters to freshwater and marine organisms EPA-2002 821-R-02-012, Washington, DC.

US EPA-USACOE. (1998). Evaluation of dredged material proposed for discharge in waters of the U.S.-Inland testing manual.EPA-823-B-98-004. Washington, DC: U.S. Environmental Protection Agency, Office of Water and US Army Corps of Engineers.

U.S. Environmental Protection Agency. A microwave assisted acid digestion of sediments, sludges, soils and oils. EPA3051A: 07. 